


\section{Humans and other animals in the Low Countries An Introduction}

Eric Jorink, Joanna Woodall and Edward H. Wouk

\section{Slashing Descartes}

On 18 January 1982, at the Royal Society in London, a member of the Animal Liberation Front slashed the society's portrait of René Descartes (15961650). Leaving the painting damaged, the culprit managed to escape, but the point to be made by this iconoclastic act was clear. Besides the Animal Liberation Front, many others, then as well as now, have pointed to Descartes as the advocate of a dualist separation between mind and matter, soul and body, and a consequent ontological distinction between humans and animals. ${ }^{2}$ In his seminal essay 'Why look at animals' (1977), John Berger sketches a broad overview of human-animal relationships in human culture. ${ }^{3}$ As Berger reminds us, the oldest remaining artifacts of human culture consist of images of animals. To humans, animals were at the same time sources of food, tangible connections to the spiritual world, company and perhaps even objects of care. During the subsequent millennia, this close, holistic, multifaceted relationship changed into a largely instrumental one. A highly urbanized and industrialized society started to consume animals as commodities, subdued them in public zoos, idealized them in children's books and kept them as pets. Everyday tactile and visual contact changed into gazing through iron bars and the photographic lens - or removing cows, pigs and chickens from view. From Berger's perspective, the philosophy of Descartes, who spent more than 20 years in the Dutch Republic and published all his major works there, marks a turning point, creating conceptual and physical boundaries between humans and other animals. The decades after Berger's essay have witnessed the further rise of movements for animal rights, and the emergence of the academic discipline of animal studies. Within both - partially overlapping - fields, Descartes has been pinpointed as a key, symbolic figure. ${ }^{4}$

This volume of the Netherlands Yearbook for History of Art / Nederlands Kunsthistorisch Jaarboek is devoted to humans and other animals in the art of the Low Countries. Its title takes cognisance of the cross-disciplinary field of animal studies, which challenges taxonomies that set human beings apart from, and often above or at the centre of, all other living creatures and the broader environment. The volume aims to contribute new research to a burgeoning field at the intersection of animal studies and art history. Stimulated by political and ethical concerns, animal studies has entered academic discourse, resulting, for example, in the publication of important surveys including the Oxford handbook of animal studies (2017). ${ }^{5}$
Detail fig. 9 
1

Hendrick Goltzius, A Seated Monkey on a Chain, 1592-1602, black, ochre, and red chalks, $406 \times 300 \mathrm{~mm}$, Amsterdam, Rijksmuseum, inv. no. RP-T-1888-A-1510 (photo: Rijksmuseum).
As Erica Fudge, director of the British Animal Studies Network, has argued, animal studies is not about writing a history of animals, but questioning anthropocentric views of the world and challenging the human presumption to privileged status. ${ }^{6}$ Far from being an independent, stable subject, humans have often defined themselves in relation and opposition to animals, a point already made by Michel Foucault (1926-1984) and Jacques Derrida (1939-2004).7 Questioning traditional dichotomies between humans and animals, between culture and nature, scholars as well as political activists point to the ethical basis and social and ecological effects of vivisection, bio-industries and biodiversity. Do non-human animals have rights? Are they able to communicate? Is there in fact a sharp anatomical and ontological distinction between humans and other animals? Should humans give other creatures human names?

Such questions have opened lines of inquiry specific to historians of art and visual culture: What are the politics and ethics of studying human representations of other animals? What are the philosophical and moral implications of using animal materials in works of art and representation, be they pigments, skins, butterfly-wings, ivory or tortoiseshell? Some of the authors in this volume have taken their inspiration from such questions. Since ancient times, the arts have reminded people that they live in a morethan-human world. ${ }^{8}$

In the Low Countries early forms of systematic domestication and reproduction of cattle had already emerged in the Middle Ages. ${ }^{9}$ With the creation of global trading networks in the sixteenth and seventeenth centuries, there was an influx of reports and actual examples of previously unknown animals, especially in Antwerp and, later, Amsterdam. ${ }^{10}$ The European iconography of - for example - the giraffe, the rhinoceros, the elephant or the civet cat can be traced back to just a few datable physical encounters with individual specimens, some of which took place in the Netherlands. Up to c. 180o, very few of these exotic animals were to be seen in Europe, and most of them were on tour. ${ }^{11}$

The first-known visual representations of many species often show the animal with a collar - a sign of their captivity and possession, not only by human agents but also by the image itself..$^{12} \mathrm{An}$ article in this volume includes the earliest-known image of a civet cat, depicted wearing a collar, by Ludger tom Ring the Younger (1522-1584) in about 1560 (see fig. 6 at p. 39). Another moving example is the Asian rhesus monkey on a chain captured in black, ochre and red chalks by Hendrick Goltzius (1558-1617) and reproduced on the cover of this volume (fig. 1). This image, drawn between 1592 and 1602, belongs to a visual tradition of 'art the ape of nature' arguably most familiar in the Netherlandish context from Peter Bruegel the Elder's Two monkeys of ${ }^{1562 .}{ }^{13}$ Bruegel's small painting represents two alert animals, identified as red colobus monkeys, chained to a large iron ring attached to the windowsill of a stone building - possibly a prison - that overlooks a harbour widely considered to be that of Antwerp. ${ }^{14}$ In Goltzius's drawing, the anthropomorphism is produced by the upright, seated pose in an enclosed setting, the rather portrait-like, view of the head, the pensive facial expression and the 'hand' delicately fingering the fetter. As the word 'ape' implies, we perceive these animals to imitate our human condition. In addition 


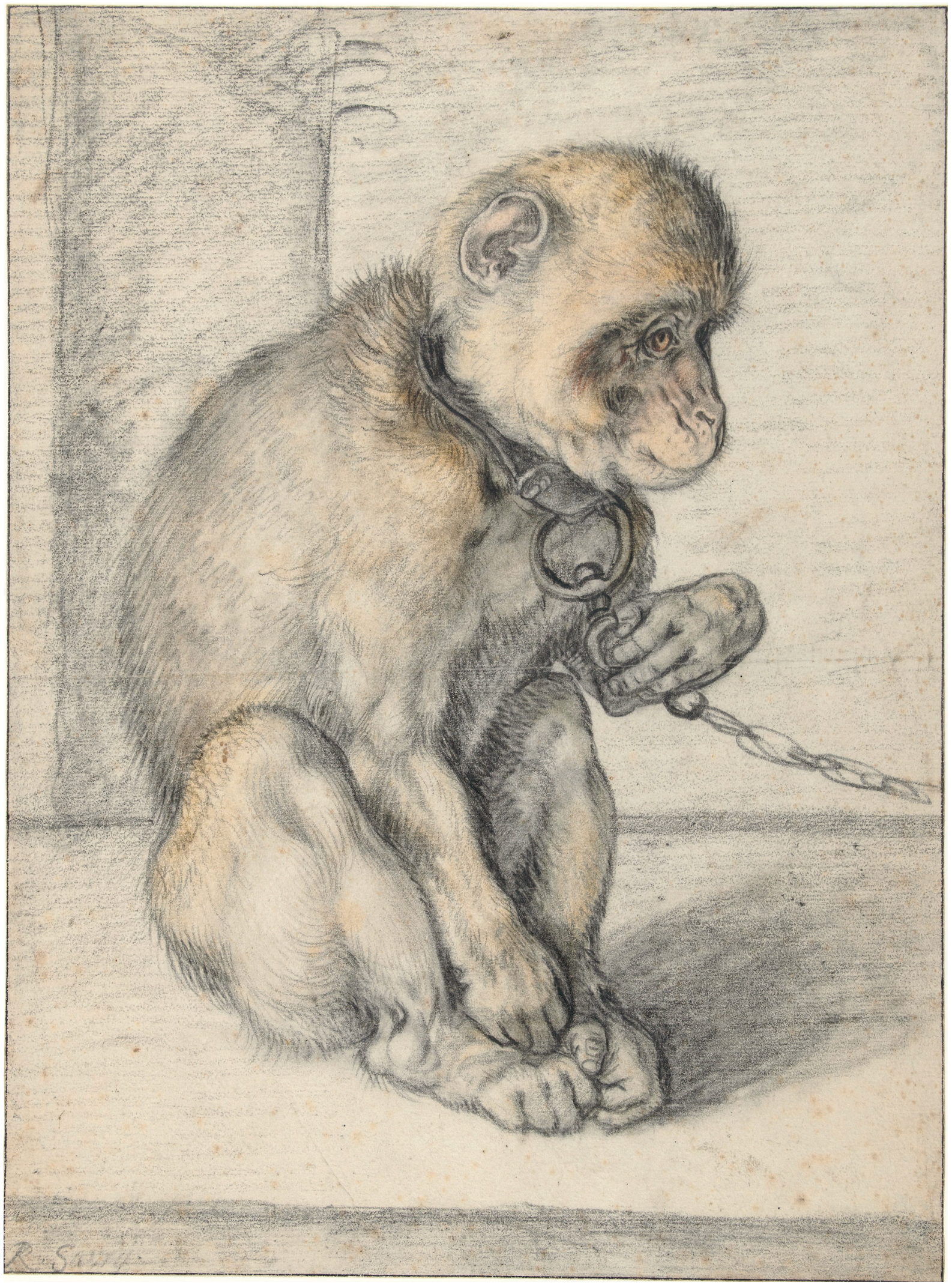


Maarten de Vos and Adriaen Collaert, America, c. 1590, engraving, 207 x 259 mm, Amsterdam, Rijksmuseum, inv.no. RP-PBI-6o6o (photo: Rijksmuseum). to symbolizing sinful humanity, shackled to the earth through its lust for wealth, a fettered monkey thus alludes to the chain of imitation and likeness that links animals and humans, art and nature. An unsettling parallel can be drawn between Bruegel's and Goltzius's imprisoned, subjugated creatures and the enslaved human beings depicted later in the century. ${ }^{15}$ Yet according to David Bindman, "The philosophical arguments against slavery [in the eighteenth century] were invariably based on the universality or brotherhood of man, which in turn rested on the implicit moral difference between man and animal. ${ }^{16}$ However, while 'all men are created equal', this did not translate into equality of, for instance, gender or ethnicity. ${ }^{17}$

European pretensions to physical and ideological domination over the world were often symbolized by the possession and appropriation of animals. Lions could be tamed, monkeys and elephants caught, bears shot and crocodiles stuffed. Artists such as Maarten de Vos (1532-1603) in Antwerp imagined the rewards, risks and revelations of the four continents primarily in terms of their distinctive peoples and animals. For example, his design for a sensational and influential engraving of America published between 1586 and 1591 is dominated by an 'Amazonian' woman in feathered head-

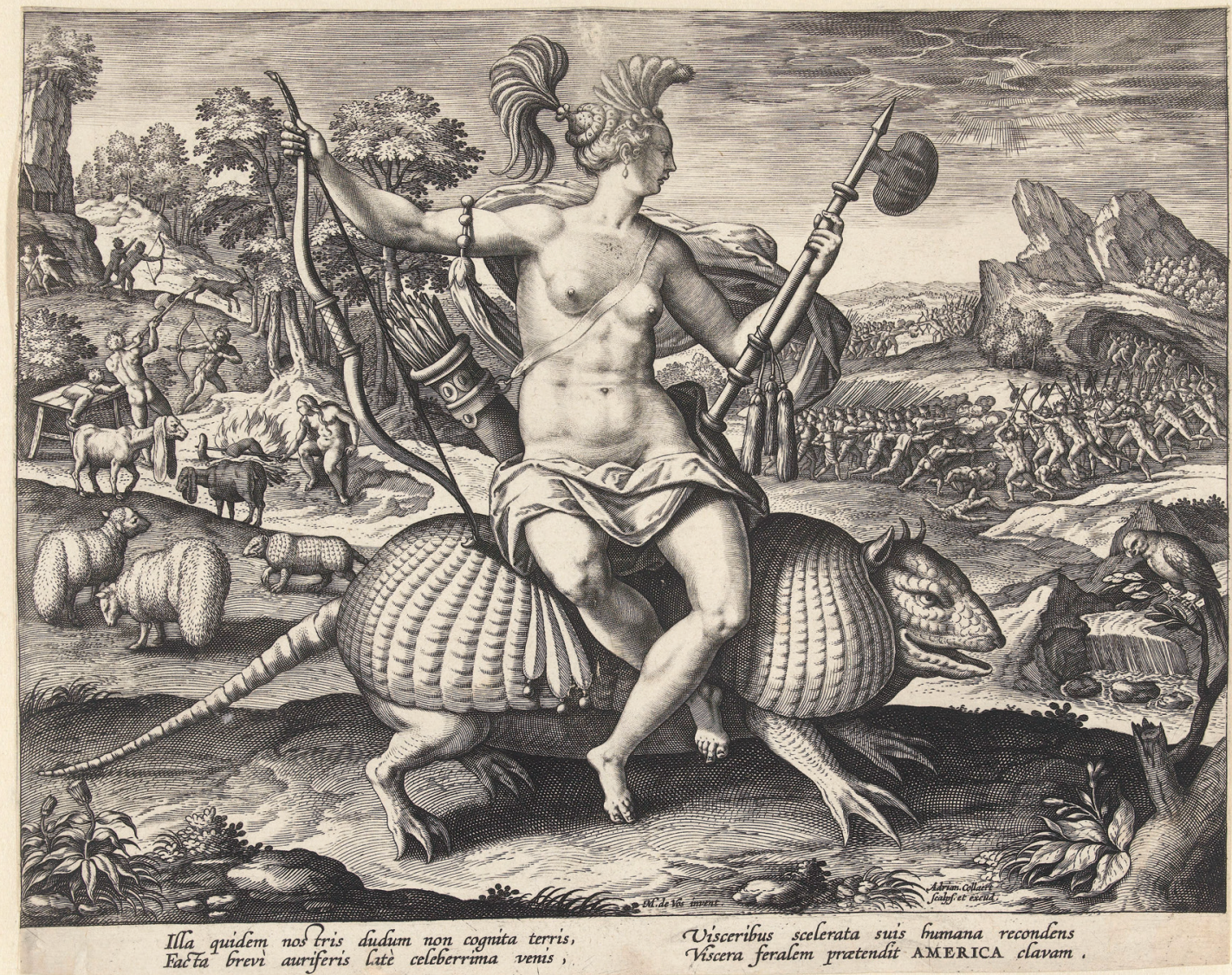


dress riding an enormous armadillo, with human beings the preferred food among sheep, goats and armadillos in the background (fig. 2). But, as one author discusses in a contribution to this volume, one animal was consistently visualized ferociously defying European human domination: the polar bear, ruler of the Arctic. In 1610 a polar bear's jawbone became an item of display at Leiden University, representing a murderous encounter some years earlier. The jawbone is just one example of the slippages between animal remains, living creatures and works of representation, whether drawn or written accounts, paintings or printed records.

This volume focuses on the timespan of about 500 years between the establishment of a rather stable rural and urban society in the Low Countries during the later Middle Ages and the huge social and ecological impact of industrialization..$^{18}$ Extending the chronological reach of the volume, one article examines the use of animal materials in the works of a seventeenth-century and a contemporary artist. ${ }^{19} \mathrm{~A}$ number of the authors are concerned with seventeenth-century oil paintings by canonical artists, a privileged subject of Netherlandish art history. One article, however, turns the tables to explore how the 'creatureliness' common to humans and other animals informs a depiction by a little-known artist of the slaughtered, eviscerated bodies of the politicians and brothers Johan and Cornelis de Witt (1672-1675, fig. 1 at p. 6o). ${ }^{20}$ Others consider the visual construction of human knowledge of selected animals in the early modern period across a range of media up to and including a study of colour lithographs arising from the Dutch naturalist and early environmental movements in around $1900 .{ }^{21}$ A number of the articles explicitly connect their historical analysis with humanity's relationship with other animals in the present day, especially human exploitation and extermination of fellow creatures, which are affecting not only the animals themselves but also the condition of the entire planet. Together these contributions recognise the need for new and cross-disciplinary approaches to the study of humans and other animals in the Low Countries.

\section{Conflicting traditions}

Far from drawing a consistent distinction between humans and other animals, the legacy of antiquity was highly ambiguous, as early modern students of nature increasingly became aware. ${ }^{22}$ In the fables attributed to Aesop (c. 620-56o BCE), animal behaviour was anthropomorphized and, hence, made accessible and useful. However, two centuries later Plato would draw a sharp philosophical and ontological distinction. 'Man' was the highest being in the sensible world of temporary representations, presiding over creatures in various states of perfection. The influential Christian idea of the scala naturae, the 'great chain of being' with 'man' at the summit of all creatures, dominating the 'brutes', cattle, birds, fishes and the creeping 'lowest' stages of life, had its origin in Plato's writings (fig. 3$)^{23}$ Aristotle and later philosophers postulated a less clear-cut distinction, and observed similarities in human and animal behaviour. In his Historia animalium, for example, Aristotle states: 
In a general way in the lives of animals many resemblances to human life may be observed. Pre-eminent intelligence will be seen more in small creatures than in large ones, as is exemplified in the case of birds by the nest building of the swallow. In the same way as men do, the bird mixes mud and chaff together (...) it makes a bed of straw, putting hard material below for a foundation, and adapting all to suit its own size. Both parents co-operate in the rearing of the young. ${ }^{24}$

Yet, it is noteworthy that Aristotle also writes that 'Man is the only one of the animals known to us who has something of the divine in him.. ${ }^{25}$ Pliny the Elder, whose Natural history enjoyed the same authority as Aristotle's works in pre-modern Europe, shows a similar, complicated attitude. Pliny explicitly includes humans in the broader category of animals, noting, for example, that 'man is the only viviparous biped', and 'only man is unable

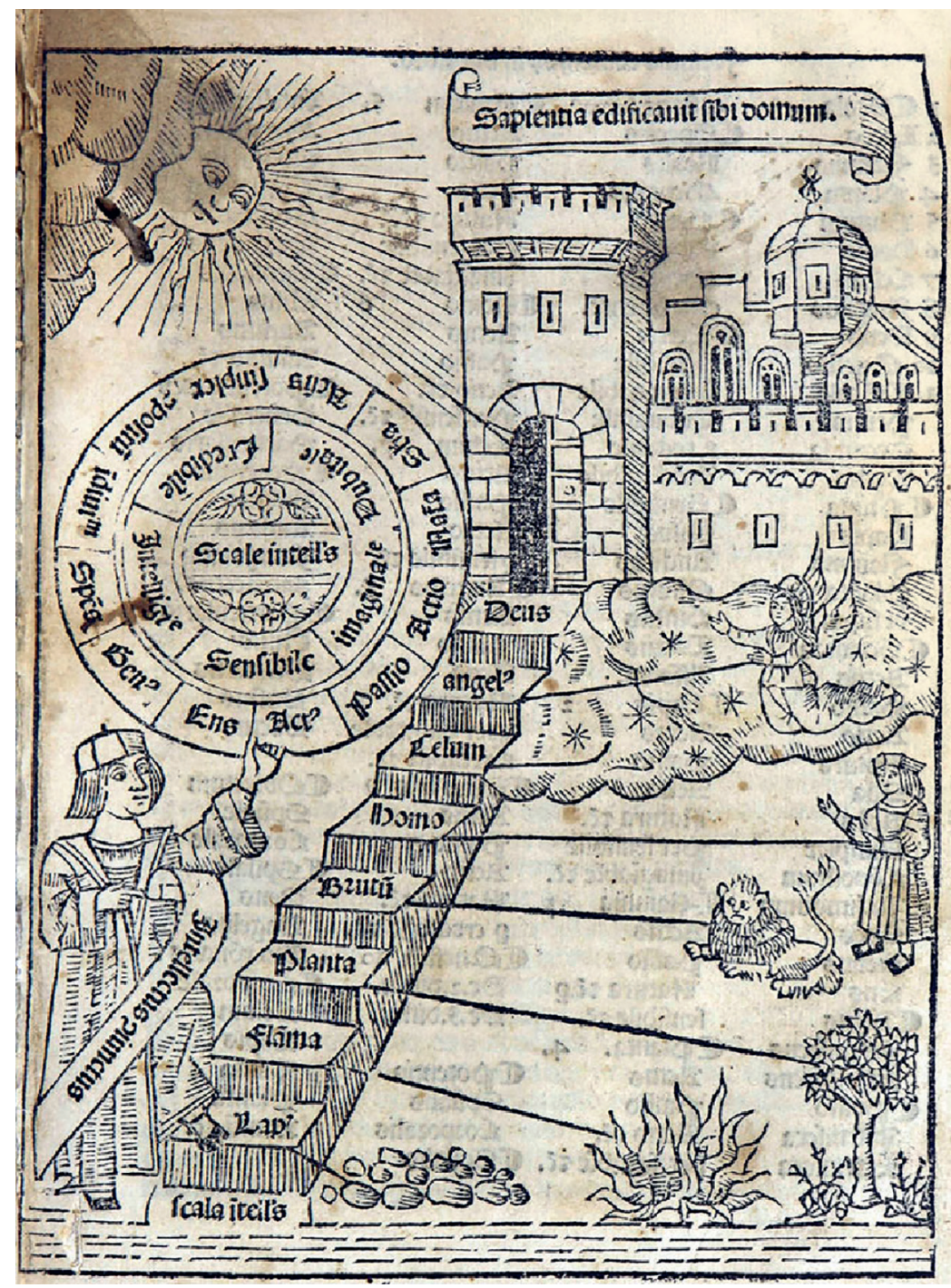


to move the ears. ${ }^{26}$ In his quest to give a complete account, Pliny imputes human-like characteristics to animals and deploys different registers of description. An example is his account of the elephant, 'nearest to man in intelligence'. The largest land animal 'is pleased by affection and by marks of honour; nay more, it possesses virtue rare even in man, honesty, wisdom, justice, also respect for the stars and reverence for the sun and moon.' ${ }^{27}$ Pliny was also interested in the elephant's fear of mice and mortal antipathy for snakes. At the same time, he describes ivory as 'a very elegant material for images of the gods' and the presence of elephants in military campaigns and in circuses in Italy.

As later humanist scholars increasingly became aware, Aristotle and Pliny were not the only pagan authorities writing on animals. ${ }^{28}$ Pliny's thoughts at times came close to those of writers in the Stoic and Epicurean traditions. At a very basic level, these thinkers rejected the ontological separation of human beings from the rest of the cosmos. Anticipating by many centuries the Cartesian theory of matter, the Stoics postulated a universe filled with pneuma, and the Epicureans with atomae, the tiny particulate constituents of everything. ${ }^{29}$ At this fundamental level, everything consisted of the same matter and obeyed the same lex naturae. Everything in nature, including humans and other creatures, was thus related and corresponded. In this holistic view there was no absolute difference between microcosm and macrocosm, great and small, living and dead, human and animal. Importantly, such ideas had practical consequences - leading, for example, to the refusal by Pythagoras (c. 570-c. 495 BCE) and Epicurus (341-27o BCE) to eat meat. Ovid (47 BCE-17 CE), in his extremely influential Metamorphoses, uses distinctions between the gods, human beings and the animal kingdom to explore the frisson of transgressing boundaries.

Genesis clearly states that God created all the animals, and finally, as a crown on His creation, 'Man'. And God spoke: 'Be fruitful, and multiply, and replenish the earth, and subdue it: and have dominion over the fish of the sea, and over the fowl of the air, and over every living thing that moveth upon the earth'. ${ }^{30}$ To seal this dominance, Adam gave names to all the animals. Whereas humanist scholars debated the identification of individual species, the order of creatures was clear. These anthropocentric views in Christianity were confirmed by The physiologus, an anonymous Greek source translated into Latin in the fourth century. ${ }^{31}$ Animals are relevant for man, in so far as they teach divine lessons. For example, the absence of lust attributed to elephants meant that they were seen as inhabitants (and survivors?) of Paradise before the Fall. Rembrandt may have played on this idea in his Adam and Eve etching of 1638 (fig. 4), in which an elephant in the background, placed strategically to draw a comparison with Eve, remains in the garden at the moment she passes the apple to Adam.

Printing played a critical, but underestimated, role in reshaping human-animal relations, although very few of the incunabula printed in the Low Countries from 1460 had illustrations of animals. One exception is the travel account Peregrinatio in Terram Sanctam, translated into Dutch in 1488, and illustrated by the Utrecht artist Erhard Reuwich (precise dates unknown). $\cdot^{2}$ For the first time, a camel, a giraffe, a crocodile and a unicorn were captured in print (the latter, the writers claimed to have seen only 


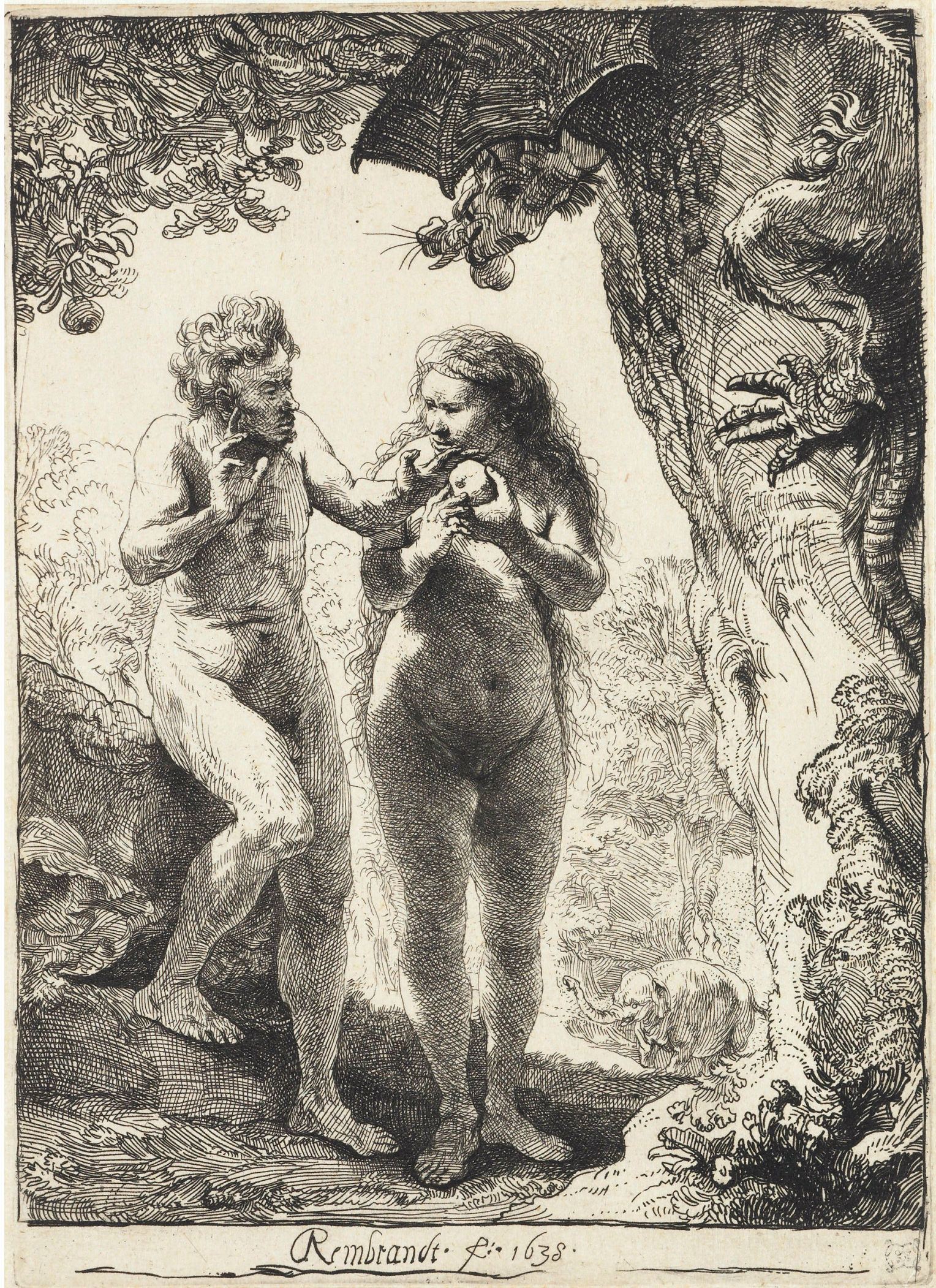


from very far away) (fig. 5). Ultimately, however, besides diffusing texts on humans and animals on a large scale, the technology made possible the inclusion of printed illustrations, thereby standardizing visual representations and enabling comparison. ${ }^{33}$ European readers knew what a cow, a starling or a bee looked like, but the printing press offered the opportunity of getting to know creatures only known from hearsay - or that were simply beyond imagination. Prints provided a template, as well as a perceptual framework, resulting in self-reproductive observations and motives. ${ }^{34}$ The iconic woodcut by Dürer of the rhinoceros is a well-known example of a printed image that continues to shape our perceptions of an 'exotic' animal and its temperament. ${ }^{35}$

By far the most ambitious and influential attempt to describe and visualize the (then known) world was undertaken by the Swiss humanist Con-

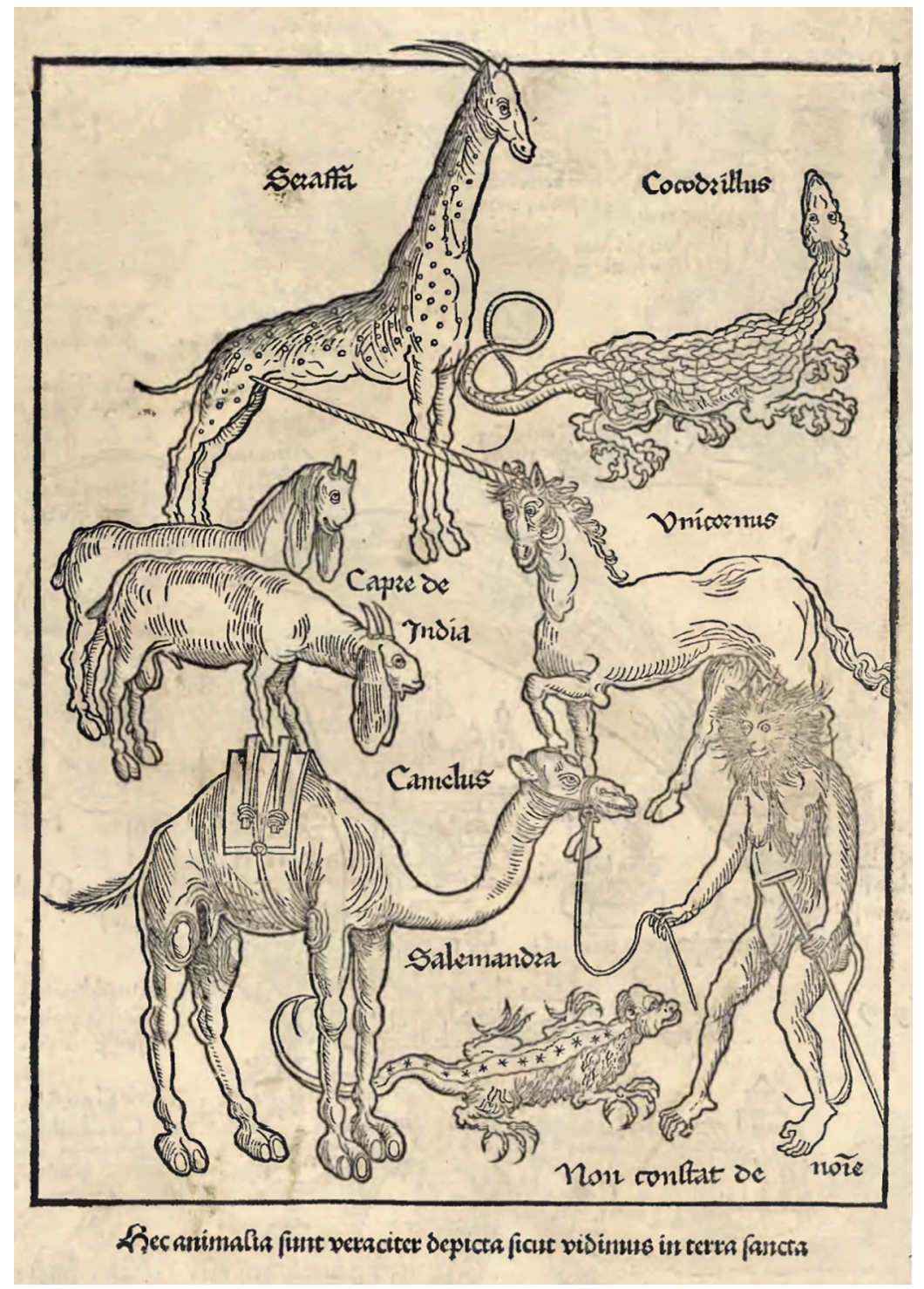

4

Rembrandt, Adam and Eve in Paradise, 1638, etching, $163 \times 117 \mathrm{~mm}$, Amsterdam, Rijksmuseum, inv.nr. RP-P-1961-992 (photo: Rijksmuseum).
5

Erhard Reuwich, Exotic animals, 1486, woodcut, $269 \mathrm{~mm} \times 198 \mathrm{~mm}$, Bernhard von Breydenbach et al., Peregrinatio in Terram Sanctam (Mainz 1486) (photo: public domain). 
Martin Schongauer, Elephant, c. 1485, engraving on ivory laid paper,

$102 \times 130 \mathrm{~mm}$, Chicago, The Art Institute of Chicago, inv. no. 956.912 (photo: The Art Institute of Chicago). rad Gessner (1516-1565). ${ }^{36}$ Notably, he did not include a description of the human species in his five-volume Historia animalium published in Zurich over a period of more than 30 years from $1551 .^{37}$ Gessner emulated his predecessor Pliny in seeking to provide a comprehensive view. He attempted to collate everything that had ever been written about a specific creature, and he added first-hand observations. He also included as many printed images as possible. The copious illustrations visualize these rich characterizations. For the elephant, for example, Gessner used Martin Schöngauer's engraving of one of the earliest elephants brought to Europe (1483) as his source (figs 6 and 7) $\cdot^{8}$ This would become the template for depicting elephants in the subsequent decades. In the systematic lemmata following the illustration, Gessner summarizes all knowledge at his disposal, starting with the creature's names in ancient languages. Subsequent entries extract and enumerate sources describing the elephant's appearance on coins and in fables; the animal's sympathies and antipathies (the elephant and the rhinoceros are sworn enemies); and many other details that produce what is arguably a richer even if more explicitly anthropocentric account than later natural history would admit. Until Carl Linnaeus (1707-1778), knowing a creature consisted not of describing its anatomy, generation and habitat, but of

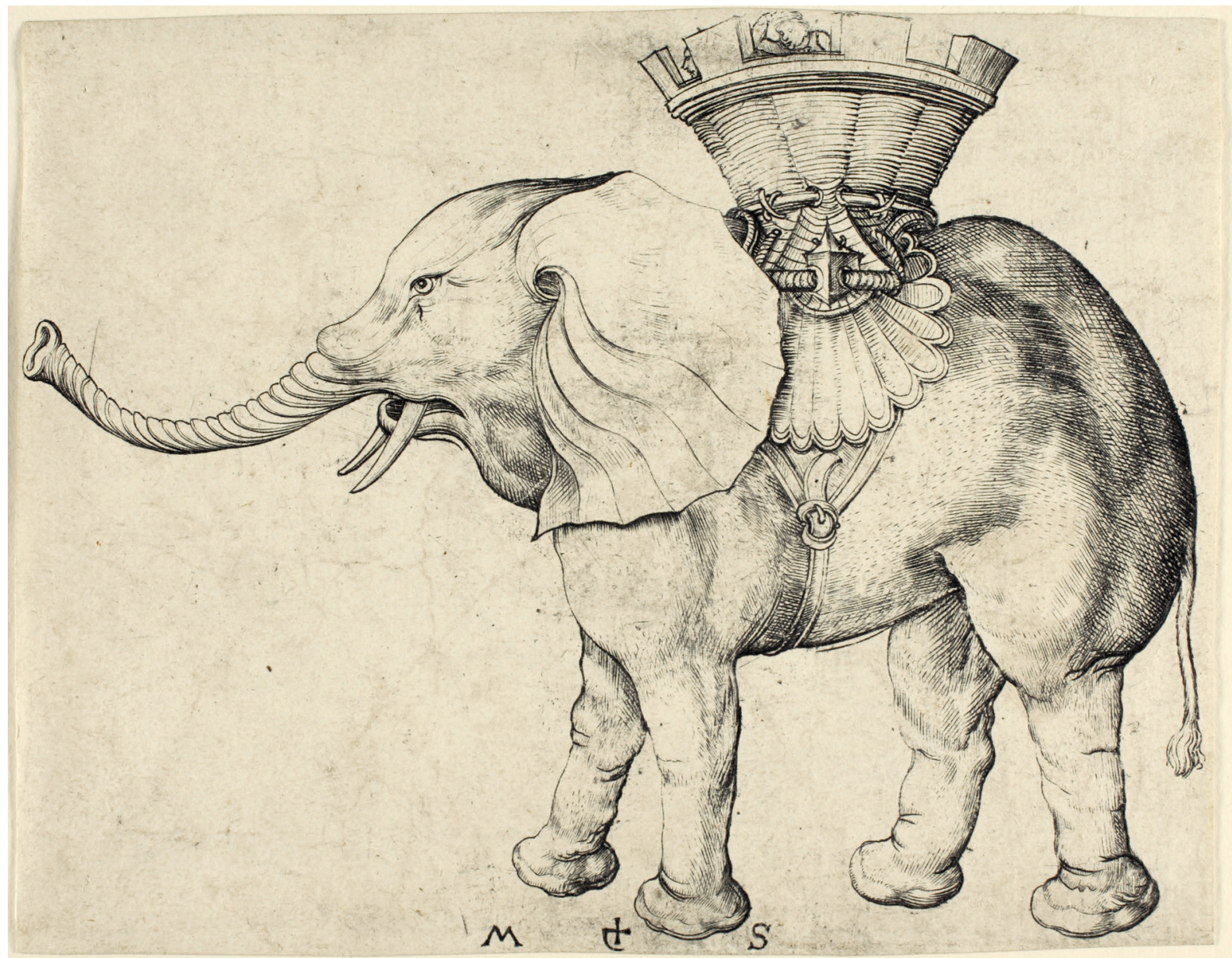




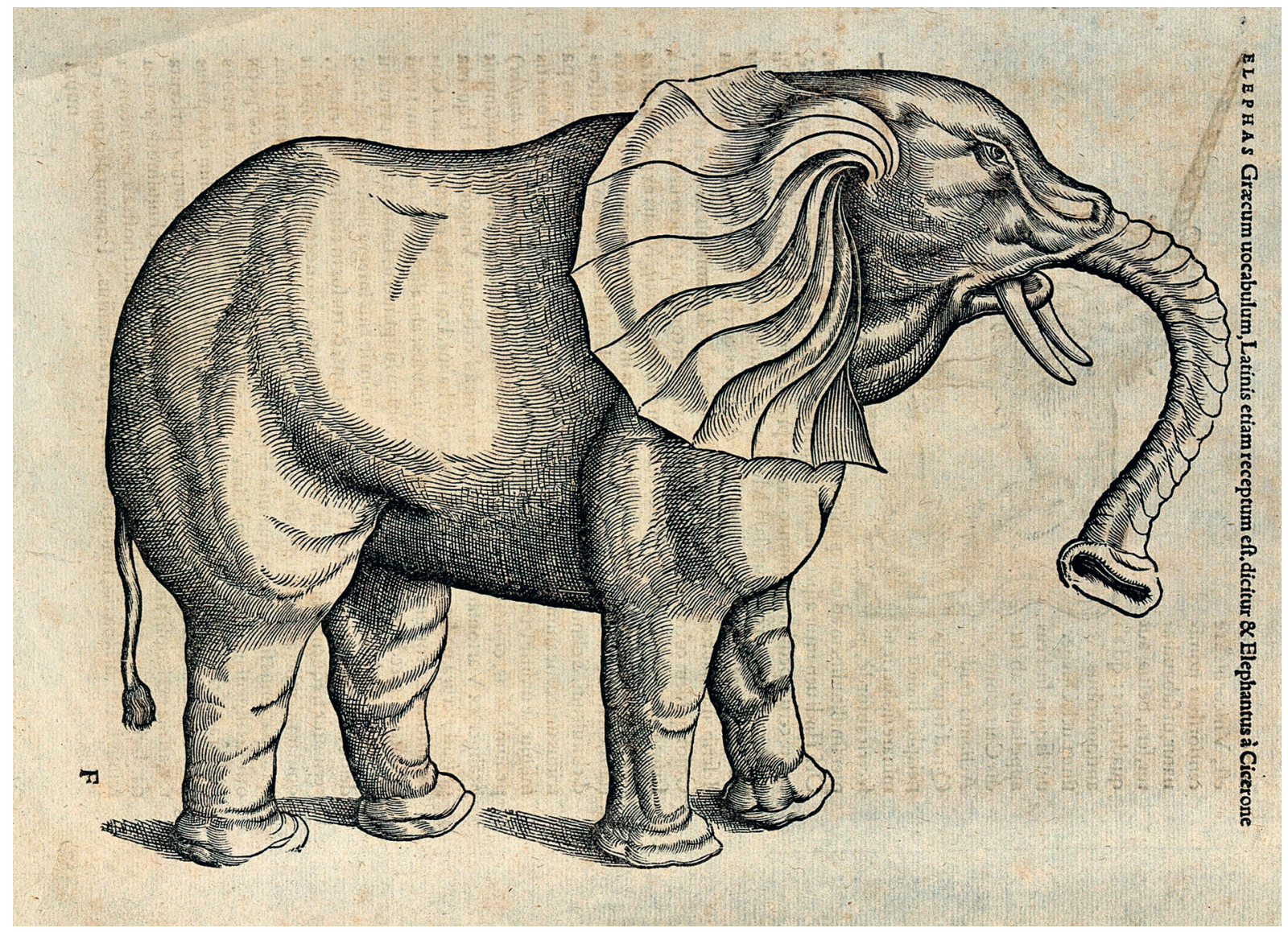

painstakingly reciting every known fact about and aspect of it, including perhaps most of all - its significance and usefulness to man. Natural history was narrative and hermeneutic, rather than descriptive and taxonomic.

Alciati's Emblemata (1531) appeared two decades before the first volume of Gessner's great work was published. Books of emblems, like nature itself, were seen as sources of an endless variety of references and meanings. ${ }^{39}$ In the wake of Les mots et les choses by Michel Foucault (1966), William Ashworth coined the term 'emblematic worldview' ${ }^{40}$ Although this concept has been criticized, it is important to note that animals feature prominently in the expanding genre of the emblem book. Animals such as the monkey, the fox or the elephant were used to teach moral lessons and to symbolize occult properties and hidden meanings. In a more general sense, animals could personify specific vices and virtues, people or even entire countries.

\section{Animals in the sixteenth-century Low Countries}

The poet and huntsman Jacob Westerbaen (1599-1670) cheerfully wrote in 1652 how the same larks and finches that in the spring offered the joy of their songs, in the autumn served mankind as prey and food. ${ }^{41}$ Horses were useful in agriculture, warfare and showing-off. In terms of numbers, there
7

Artist unknown, Elephant, 1551, woodcut, C. Gessner, Historia animalium Pars I, de Quadrupedibus (Zurich, Froben, 1553), London, The Welcome Trust (photo: Welcome Trust). 
were many more horses in the sixteenth than in the nineteenth century. ${ }^{42}$ Livestock farming, especially of oxen, cows and sheep, increased rapidly in the sixteenth century, leading to what could be considered a proto-form of bio-industry. Beef cattle were brought in large quantities from Denmark and Germany, fattened up in the eastern provinces of the Low Countries and then slaughtered in the cities in the coastal area. ${ }^{43}$ Around 1600 the northern Netherlands was Europe's largest exporter of meat - a position the modern Kingdom of the Netherlands still holds today. Few could afford to buy red meat, but many prey animals were semi-domesticated. Archival records and archaeological findings indicate considerable consumption of fresh water fish, as well as ducks, herons, finches and rabbits - an animal introduced in the thirteenth century. ${ }^{44}$ Hunting for deer, swans, geese and foxes was a privilege for the nobility and elite, and subject to complicated regulations - not to protect the non-human animals from human cruelty, but to secure legal distinctions and prerogatives, to avoid damage to property or to avoid extinction..$^{45}$ A notable exception was the fearsome wolf, subject of collective drive hunts of an almost ritual character. ${ }^{46}$ One contribution to this volume explores the motif of the artist as hunter, a more aggressive imitative relationship between species than the 'art the ape of nature' topos. ${ }^{47}$ Animals were also subjected to humans in their assigned role as pets. Cats entered domestic households, and Dutch genre paintings, in considerable numbers only in the course of the seventeenth century, while a long history exists of depicting dogs in their various relations with humans. Another contribution to this volume explores the dog as pet, pest and favoured subject for anatomical dissections in the city of Leiden in the early seventeenth century.

For Reformation luminaries such as Philip Melanchthon (1497-1560) and John Calvin (1509-1564), looking at animals was looking at God's creatures, and His Creation was a primary subject of study. The articles of faith of the Belgic Confession (1561) - drawn up in Antwerp by Guido de Brès (1522-1567) and approved by Calvin himself - state that God made himself known by the Bible and by the Book of Nature:

We know him [God] by two means. First, by the creation, preservation, and government of the universe, since that universe is before our eyes like a beautiful book in which all creatures, great and small, are as letters (...) Second, he makes himself known to us more openly by his holy and divine word..$^{8}$

This was strong encouragement to observe, study and represent nature, including the smallest of creatures, insects, as Joris Hoefnagel (1542-c. 1600) then started to do in astonishing detail (fig. 8).49 This new approach was towards an emblematic reading of nature, from both artists and others. The publication of the famous and extremely influential Warachtighe Fabulen der Dieren (Bruges 1567), illustrated by Marcus Gheeraerts I (c. 1520-c.1590), can be seen in this light..$^{50}$ Gheeraerts made optimal use of the possibilities of the new medium of etching. As a convinced and convicted Protestant, he strove towards lifelike representation of all creatures, basing his work in part on Gessner as well as on his own observations..$^{5^{1}}$ 


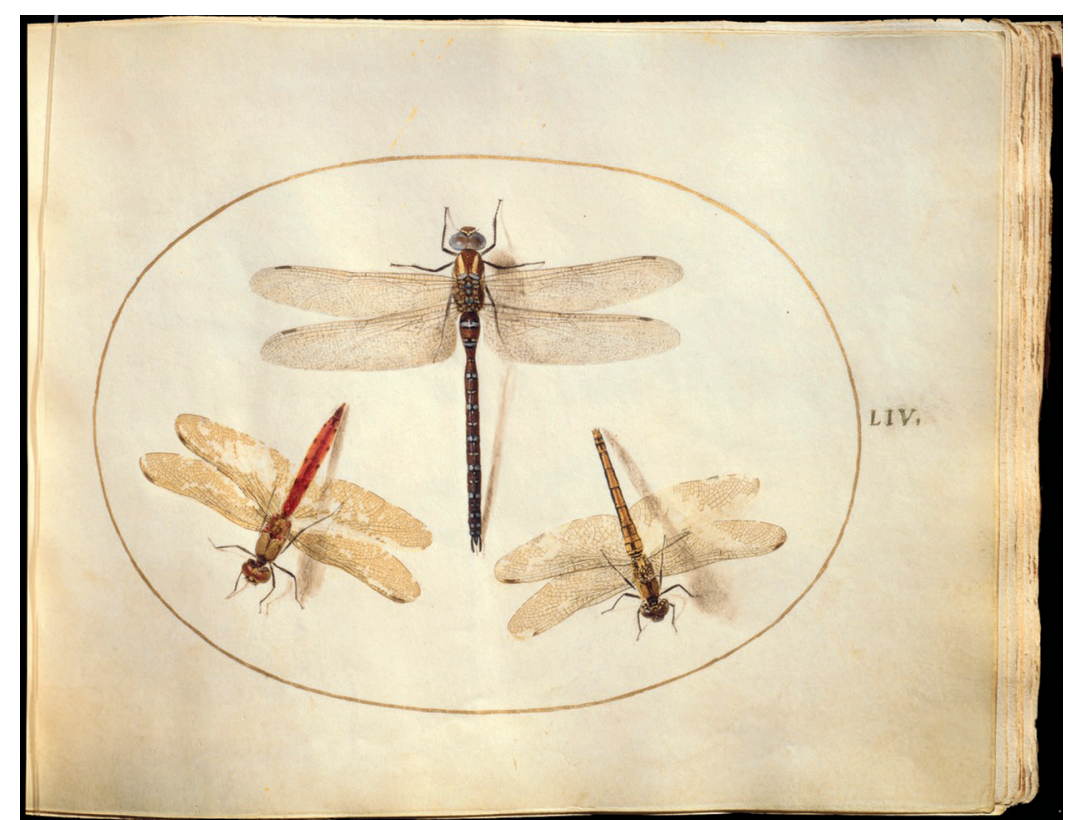

Hoefnagel's home city of Antwerp never saw the publication of systematic work on animals, in contrast to the many works on botany that were published there. This was no doubt due to the availability of the all-encompassing work of Gessner. Later, Dutch publishers would fill this niche, serving a religious sense of wonder as well as commercial interests. ${ }^{5^{2}}$ As Marrigje Rikken and others have shown, the depiction of the ever-expanding kingdom of animals also provided new motifs as well as an expanding market for artists. In Antwerp a lively industry emerged in the production of prints, paintings, cabinets and other works of art displaying animal figures, often in a cosmological setting, referring to the elements and continents. ${ }^{53}$

In the northern Netherlands, by 1600 , many exotic and previously unheard-of animals were captured and carefully observed, described and drawn, being precious commodities and subjects of pious wonder, often at the same time. ${ }^{54}$ But anthropocentric perspectives on exotic animals - for example, on monkeys and parrots - remained the norm, as seen in the case of Goltzius's drawing of the captive monkey, discussed above, where the careful observation, large size of the sheet and use of chalks serve to portray the animal as if it were a human subject. A different kind of anthropocentrism is evident in the well-known case of an elephant given the name Hansken. In 1630 this young elephant was captured in Ceylon and shipped to the Netherlands, as a gift to the stadholder, to symbolize the Republic's dominion over Asian nature. ${ }^{55}$ The young female elephant was sold as a commodity to the Amsterdam merchant Cornelis van Groenevelt (16161665). Teaching the intelligent animal all kinds of tricks, Groenevelt toured fairs profitably throughout Europe for 20 years, leaving an impressive paper trail consisting of drawings, engravings, pamphlets and written accounts. For decades, this was the only living elephant to be seen in Europe and, hence, the new template for depicting this intelligent animal. Rembrandt modelled his elephant in Paradise after Hansken herself, rather than after
8

Joris Hoefnagel, Three dragonflies in: The four elements, c. 1575-1580, original dragonfly-wings, watercolour and gouache on vellum, 143 X $184 \mathrm{~mm}$, Washington DC, National Gallery of Art, inv. no. 1987.20.6.43, fol. liv (photo: National Gallery of Art). 


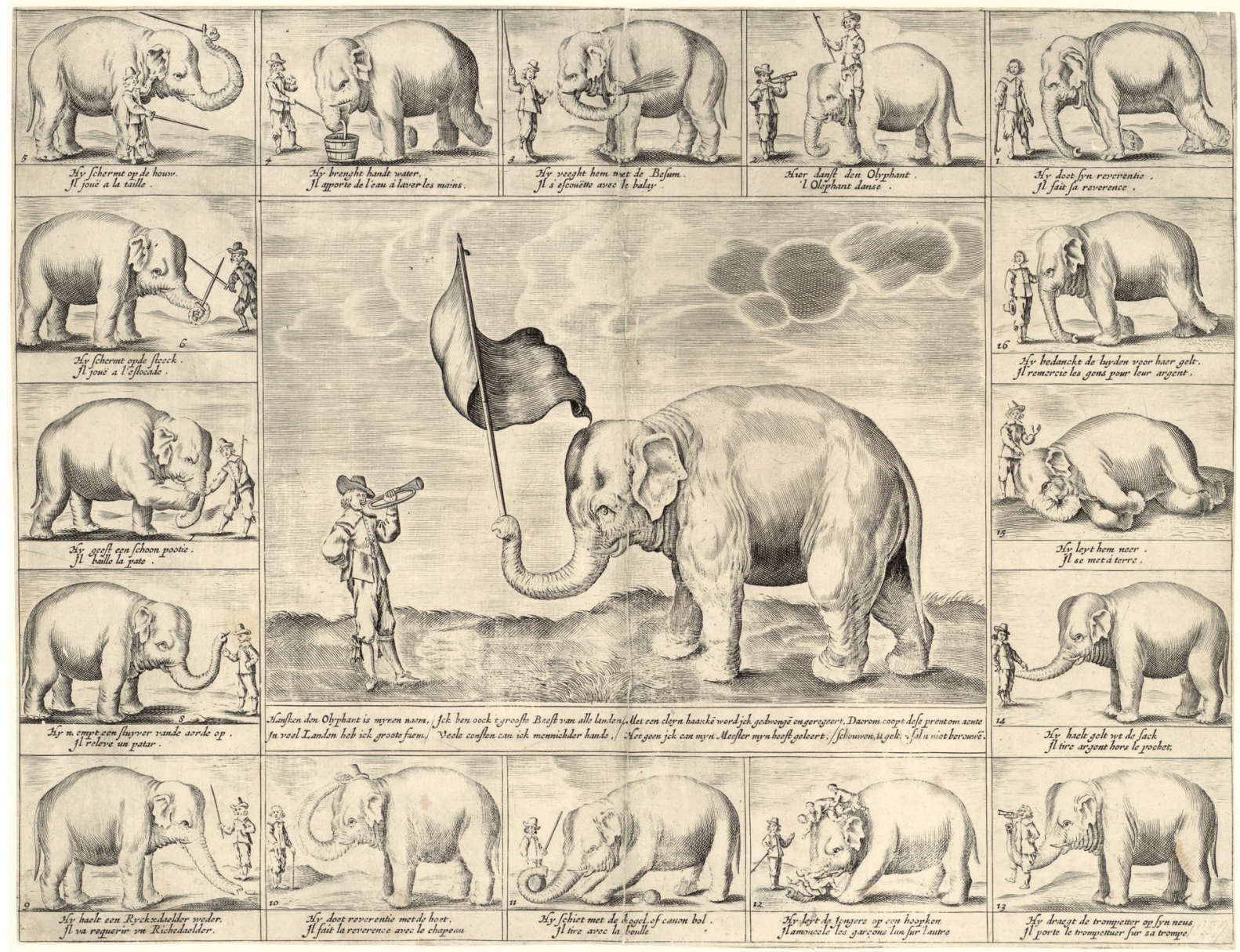

9

Artist unknown, The Elephant Hansken, c. 1650, engraving, $295 \mathrm{~mm} \times 383 \mathrm{~mm}$, Amsterdam, Rijksmuseum, inv. nr. RP-POB-77.795 (photo: Rijksmuseum).
Gessner. Hansken could wave a flag, kneel down, pretend to sleep and - in an obvious set-up - managed to identify a thief in the audience. After the acts, Hansken would collect the money donated by the audience with her trunk (fig. 9). In 1655 Hansken died in Florence. Her skeleton can still be seen in the natural history museum La Specola.

\section{Stoics, Descartes and the hierarchy of beings}

In the later sixteenth and early seventeenth century, neo-Stoicism gained new currency in the Netherlands, Rubens being the adherent best known to historians of art. The latter have usually seen neo-Stoicism as an essentially moral philosophy (with fatum and resignation being the key concepts), but, in the spirit of Cicero, Seneca and others, it was an all-encompassing philosophy of the cosmos, including natural history and physics. ${ }^{6}$ As mentioned above, in the Stoic conception of the universe everything consisted of pneuma and had the same ontological status. This meant that the hierarchical distinction between humans and animals identified above was, at the fundamental level of matter, problematic. An essay concerned with Rubens and the satyr in this volume explores a philosophical zone in 
which satyrs could exist and vegetarianism is practiced (see fig. 7 on p. 224). The French priest and natural philosopher Pierre Gassendi (1592-1655) who visited the southern and northern Low Countries in 1629 - defended Stoic and Epicurean philosophy against charges of being un-Christian (on account of its conception of matter) and wrote a defence of vegetarianism. ${ }^{57}$ Man was, by nature, not destined to kill other creatures, Gassendi writes in a letter to a friend:

[I]n fact, he shrinks in horror from seizing and rending living or even raw flesh with his teeth (...) What is clearer than that man is not furnished for hunting, much less for eating, other animals? In one word, we seem to be admirably admonished by Cicero that man was destined for other things than for seizing and cutting the throats of other animals [italics added].$^{8}$

Gassendi knew Descartes, who had just settled in the Republic. During his stay, Descartes published his influential philosophical works, starting with the Discours de la méthode (Leiden 1637), in which he famously compares the body, as distinct from the mind and the soul, to a machine. ${ }^{59}$ This axiom - so much commented upon by defenders of animals rights and scholars working in the field of animal studies - was based on Descartes's idea that everything in nature consisted of small particles and was nothing more than matter-in-motion that obeyed the same fixed laws. According to Descartes, 'man' has a rational soul. This sets him apart from animals which he considered bodies with a sensitive soul. They lack consciousness, self-awareness and, crucially, the capacity to think. For Descartes, therefore, parrots can only mimic human speech. Descartes took these birds as a pars pro toto for the entire animal kingdom. Gassendi was the first to attack Descartes on these points, making the claim that animals certainly had language - but of a different nature. ${ }^{60}$ However, it is important to stress here that a view of Descartes as inventor of a doctrine of animals as automata comparable to machines that have no feelings is oversimplified. His writings on this subject were highly ambiguous and complex. ${ }^{61}$

On the one hand, Descartes's comparison of the body with a machine had a profound impact on the study of anatomy, both human and animal, resulting in practices of vivisection. ${ }^{62}$ To give some examples: Johannes Swammerdam (1637-1680), a brilliant Leiden student of medicine most known for his research on insects, in 1661 started his career by dissecting living dogs to study the process of respiration (fig. 10). ${ }^{63}$ Three years later, he also dissected civet cats. The Cartesian agenda encouraged comparative anatomy, on subjects both dead or alive.

On the other hand, by reducing the bodies of humans and animals to mere matter-in-motion, both theoretically regained the same, equal ontological status they had already been assigned in Stoic and Epicurean philosophy. Descartes thus endorsed the traditional Christian view that man was a unique creation of God, exclusively gifted with the higher, quasi-divine faculty of a rational soul. Yet, as all living bodies - human and non-human - could be compared to functional machines, there was, in realms of knowledge such as science and medicine, no hierarchy between them, 
strictly speaking. Even the 'lowest' of creatures - snails, amphibians, insects - obeyed to the same divine laws as the creatures considered 'higher' in the traditional great chain of being. ${ }^{64}$

\section{On the contents of this volume}

Amsterdam civet cats, the subject of Sarah-Maria Schober's opening essay, bring us straight to the heart of the theme of animal studies. As Schober shows, European fascination for (and use of) civet cats is exemplary for the complex human-animal relationship, and for the fluid boundaries between art and science, nature and culture, ferocity and domestication. A species

\section{0}

G.Wingendorp, Frontispiece Johannes Swammerdam De respiratione, 1667 engraving, 93 x $213 \mathrm{~mm}$, Johannes Swammerdam, Tractatus physicomedici-anatomicus de respiratione (Leiden, Gaasbeeck, 1667) Leiden, Universiteitsbibliotheek (photo: Universiteitsbibliotheek Leiden Special Collections).

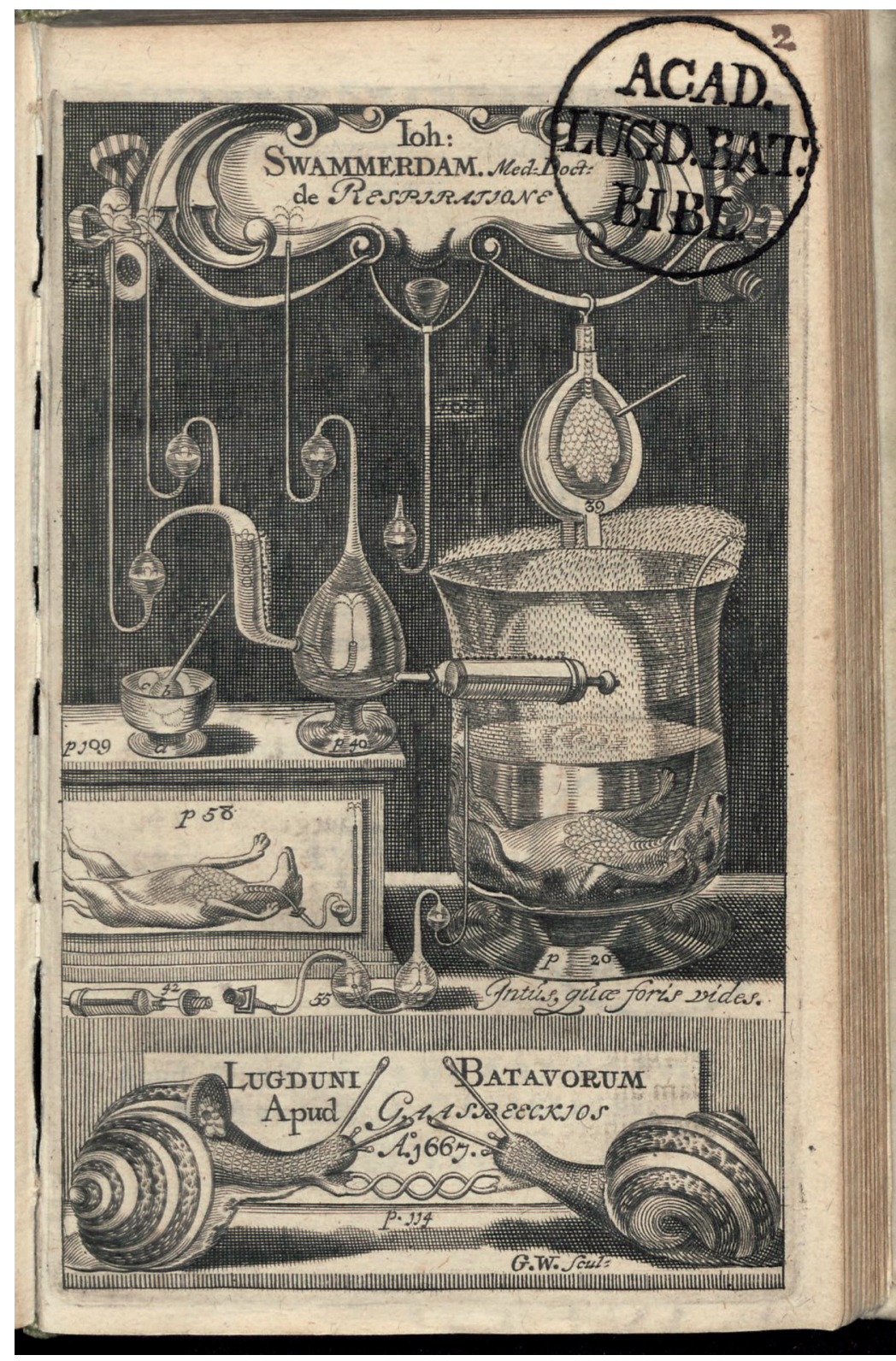


unknown to the ancients, the civet cat captured the attention of Europeans in the early modern period, on account of both the perfume that could be produced from excretion taken from the animal's gland, and its mysterious nature, to which - in accordance with the 'emblematic worldview' - many different meanings could be attributed. Symbolizing the untameable wilderness of exotic continents, and hence European dominion over nature, the creatures were captured, turned into commodities, bred and kept at courts and at the heart of the centre of global trade, Amsterdam. Schober further points to a fact that is equally scientific as symbolic in nature: it was actually civets that transmitted the SARS-CoV virus from bats to humans in 2003 - hence pre-figuring the pandemic of 2020. And, as Schober argues, the history of the dichotomy between human and non-human animal relationships is not one of two distinct realms of reality, but should be viewed as merging into situated, historically and contextually specific complexes.

Anat Pick's concept of a 'creaturely poetics' proposes human-animal distinctions as a site of contestation, anxiety and ritual. Pick's insights provide a point of departure for 'Creating and unmaking the political body', in which Thomas Balfe examines a small, disturbing painting, The bodies of Johan and Cornelis de Witt, attributed to Jan de Baen (1633-1702), as a test case in applying non-anthropocentric approaches to early modern Dutch art. The object at the centre of Balfe's inquiry belongs to, yet also stands apart from, a large quantity of visual and material culture that sought to represent, and often profit from, the portrayal of the sensational and grisly killing of Johan de Witt, de-facto leader of the United Provinces. Together with his brother, the commander and statesman Cornelis, Johan was disembowelled by a crowd in a gruesome frenzy in The Hague on 20 August 1672. Setting aside the factual reconstruction of the killing and its value as a news item, Balfe instead examines how this image portrays the bodies of these two figures being brought to the limits of humanity through an act of abject violence and through the visual spectacle of this 'butchery'. Allowing for the potential shared embodiedness of human and non-human actors opens a space for seeing this image - a nocturne of maimed corpses hanging upside down from a pole - as a challenge to human integrity and exceptionalism. Balfe's essay focuses on the formal manoeuvres of the image, including inversion, exposure and unmasking, to consider the ways in which the body is shown in a perpetual state of dismemberment that both recalls and moves between visual cultures of execution, animal slaughter and anatomical dissection. He further situates this scene in relation to a society familiar with iconoclasm and the meaningful display of disfigured images of power. In doing so, Balfe probes how the 'unmaking' of these bodies, in a political act of killing, dehumanized both victims and aggressors in ways that challenged core ideals of the new Dutch Republic, including the rational exercise of authority by its citizenry.

Violence is also the subject of Robert Bauernfeind's contribution to this volume. Exploring the arctic seas in the 1580 s to discover a short route to China, Dutch sailors were famously stranded on Novaya Zemlya. 'Het behouden huys' of Willem Barentsz (c. 1550-1597) and his crew has become an icon of Dutch history. Bauernfeind describes how not the failure of the mission itself, but the violent encounters with polar bears became the real 
shock for contemporaries. Whereas arctic expeditions could give humans the illusion they could dominate all the seas, continents and the largest creatures - whales - sailors and settlers had to compete for food with the most fearsome of all animals, polar bears. Bauernfeind describes how in books, maps and paintings these often-violent encounters were represented. As he concludes: 'In contrast to most of the other animals that have been depicted in connection with European expansion, the polar bear evades control'.

Images of human-animal interaction and aggression feature prominently in other forms of art produced around 1590 - for example, in the context of the violent struggle for political autonomy in the northern Netherlands. While scholars have examined the political resonances of the relationship between mythological combat scenes among burly gods from a variety of angles, the approaches offered by the field of animal studies open new ways of thinking about the meanings and values ascribed to representations of inter-species interfaces in the context of the new Republic. In 'Relative values. Locating the animal in three paintings by Cornelis van Haarlem', Albert Godetzky proposes novel ways for thinking about relationships between bodies and the body politic. His essay looks at three large paintings by Van Haarlem, The followers of Cadmus devoured by a dragon, The fall, and The battle between Hercules and Achelous, completed between 1588 and 1590, all of which belonged to the Amsterdam merchant and collector Jacob Engebrechtsz Rauwaert (c. 1530-1597). While Italian theorists largely focused on the representation of the human body as the measure of artistic achievement, Godetzky relates these paintings to an artistic culture in which command over the human and command over the animal were upheld as paired, supreme attainments in the arts. According to Van Haarlem's friend, the painter and theorist Karel van Mander (1548-16o6; whose treatises Godetzky examines closely), it was through visual mastery of humans and animals that a painter succeeded in representing the 'universal'. Godetzky's overarching argument is a political and ethical one, rooted in the context of the emergence of the new Dutch Republic from the violence of oppression and revolt. His analysis considers a culture of image interpretation in which relations between the human and animal were frequently figured as a means to comprehend and interpret relations between human subjects at the level of the individual and of a new national polity.

During and after the Dutch Revolt, many prerogatives and rights of the Middle Ages remained intact. As Maurice Saß demonstrates, hunting and blood sports were ritualized cultures of violence with layered meanings in the early modern Netherlands, where the killing of animals for sport, as opposed to subsistence, was associated with nobility and regulated class structures. Artists, who generally lacked noble status, were largely excluded from participating in the hunt, although they were frequently called upon to represent hunting and hunted animals, particularly when painting for courtly or aristocratic patrons. Yet, Maurice Saß's article throws light on a surprising group of artists' self-portraits which depict painters in the guise of hunters. Examining works by Gabriel Metsu, Ary de Vois and, lastly, Rembrandt, Saß reveals a range of semantic and historical valences for the artist-as-hunter that go beyond iconographical readings focused on 
the status of the artist conferred by associations with hunting. Instead, his essay advances an art-theoretical argument and considers how painters figured their relationship to dead animals around certain perceived commonalities between hunting rituals and the appropriative act of mimesis in painting as two modalities of domination over nature. Drawing upon a range of sources from classical authors to recent work in the field of anthropology, Saß presents the artist-as-hunter as a self-reflexive theme with particular purchase in the Dutch Republic, where sophisticated modes of referentiality were a feature of a rarefied market for images by celebrity painters whose works have often been associated with claims to 'realism'. These insights allow Saß to present an image as familiar as Rembrandt's $A$ dead bittern held high by a hunter within a register of artistic self-consciousness, in which the painter himself plays on connotations of capturing and picturing through mimicry and irony.

Cynthia von Bogendorf Rupprath's essay uses the story of a Leiden politician and his pet dog Tyter to shed light on the relationship between humans and dogs amid the theological-political turmoil of early seventeenth-century Leiden. The tale centres on the extravagant funeral held for Tyter in 1634 by Willem de Bont (c. 1588-1646), the chief judicial officer of Leiden's strict Counter-Remonstrant government. Tyter apparently died from being strangled and hanged by De Bont's Remonstrant opponents, and the childless De Bont's devotion to Tyter gave rise to Remonstrant satirical songs and poems, including works by Joost van den Vondel (1587-1679) and Cornelis Plemp (1574-1638). The funeral was also recorded more dispassionately in pendant paintings attributed to Jan Miense Molenaer (1610-1668) (figs. 1 and 2 at pp. 173, 174). In comparing the relationship between De Bont and Tyter with a doting parent's attachment to a precious child, these texts and images recognize profound connections between humans and other animals. At the same time, the texts in particular lampoon this deep bond as inverted, transgressive and ridiculous, thus asserting an absolute, hierarchical distinction between humans and animals. For example, the author juxtaposes Tyter's death by hanging to a legal system that could hold animals as well as their human partners responsible for crimes, but also to a city associated with violent practices of controlling and exploiting strays without a human 'master' through extermination, vivisection and eating. She links one song's claim that in grieving for his dog, De Bont mourned his revered father to the survival of the Pythagorean theory of the transmigration of souls between humans and animals, which depended upon the Aristotelian belief that both humans and animals possess a sensitive soul. On the other hand, she notes that René Descartes's Discours de la méthode, published in Leiden in 1637, states that nothing 'is more powerful in leading feeble minds astray (...) than the supposition that the soul of the brutes is the same nature with our own. ${ }^{6}$ She compares Remonstrant puns between 'Bont' and 'Hond' (dog) with anthropocentric political satire that demeans its human targets by visualizing them as 'beasts'.

While the essay is resolutely historicist and empirical, the complexity and contradictions that emerge in the relationship between 'a man and his dog' on the threshold of modernity offer a compelling reading in relation to 'postmodern' explorations of the relationship between humans and 'pet' 
animals by, for example, Jacques Derrida or Donna Haraway. ${ }^{66}$ Alongside the familiar trope of humans lording it over other animals, the history of De Bont and Tyter contains traces of human recognition of common legal existence (even if only as a subject of punishment), common sentience and a profound, existential connection with animals.

Stoic and Pythagorean ideas can also be found in the work of Pieter Paul Rubens (1570-1640), who observed that since 'man is made from the greater world or the universe', he 'carries all animals within himself'. This assumes a structural connection between the human being (the microcosm) and the cosmos (the macrocosm). The implication of this analogy is that both humanity and the cosmos are alive and contain everything, including all sentient creatures. This idea of an animate, complex, interconnected system bears comparison with present-day recognition of a living, planetary ecosystem. The microcosm/macrocosm assumes the existence of a God whose ultimate concern is the human being, and the system is generated by, and knowable through, mutual similarities and differences, sympathies and antipathies. By contrast, the components of the planetary ecosystem are linked together through nutrient cycles and energy flows that do not serve human ends, although they may be affected by human activity.

Aneta Georgievska-Shine's article situates Rubens's paintings of a human-animal hybrid, the satyr, within the pre-modern, human-centred system of the microcosm/macrocosm. In this worldview, which survives in the present day, humans define themselves in part through analogy with animals. According to Aristotle, both possess a sensitive soul, and specific non-human animals are taken to exemplify qualities such as strength (bull), courage (lion) and cunning (fox). The male goat has been attributed powerful, even excessive, sexual energy since antiquity. At the same time, elite humans, including Rubens, define themselves as different from and superior to animals in their possession of a rational, quasi-divine soul, language and moral judgement. They occupy the intellectual and disciplined realm of 'culture', while acknowledging and even celebrating the 'natural' Dionysian realm of creative instincts and ecstatic sensory experience. Incorporating features of a goat into an upright, recognizably human form with creative capacities, the satyr was both empowered and limited by embodied experience, because full humanity was believed to extend beyond embodiment.

As Georgievska-Shine discusses, the status of this being was unstable and uncertain in the early modern period. For some, including Rubens, the satyr could evoke a primeval simplicity associated with a lost Golden Age or the modern-day Arcadia of the 'New World', or it could bring to mind the wildness and natural courage of the ancient ancestors of Netherlanders, the inhabitants of Batavia on the lower Rhine. However, as well as being a subject of desire, the satyr is a threat to 'civilized' humanity's fragile construction of superiority, control and knowledge. Satyrs were compared to apes, monsters and even the devil. An association between the human-animal satyr and dark-skinned men with sub-Saharan African features is evident in Rubens's paintings, but Georgievska-Shine argues that their proximity on the human/animal continuum in his work does not imply any negative judgement of race. By exploring themes of interconnectedness 
and mutability, irony and masked wisdom in Rubens's thought-world, she emphasizes Nietzsche's conception of the satyr as 'the original conception of the human being', rather than Derrida's understanding of it as 'an animal that promises' to be raised, domesticated and disciplined into a man.

Humanity still places insects in a lowly position in the hierarchical 'great chain of being', despite their crucial importance to the ecosystem through activities such as pollination and decomposition of dead organisms, which sustain the conditions for the creation of new life. Joan Greer's article addresses representations of insect activity and habitats in the growing print culture surrounding the Dutch naturalist and early environmental movements of the late nineteenth century and the first decade of the twentieth century. It pays special attention to two works produced by the lithographer Theo van Hoytema (1863-1917): a print from 1899 that served as the cover of the artists' periodical The Garden (De Tuin), and a poster for Biological exhibition. The life of plants and animals (Biologische Tentoonstelling. Het Leven van Planten en Dieren) held at the Haagse Dierentuin in 1910 (figs. 1 and 2 at pages 250-251). In adopting the concept of 'the insect-eye view' in analyzing these intricate works, Greer invokes a form of representation that is attentive to other-than-human perspectives. While recognizing that it is not possible physically to perceive the world through the eyes of an insect, her analysis is attuned to the small in scale, and her careful, close-up looking recognizes the complex relational systems at play in insect ecosystems. Her research questions are thus consciously inspired by the work of multispecies scholars such as Thom van Dooren, and by First Nations and other non-Western thinkers' insistence on a living, intricately connected world. ${ }^{67}$ Her approach to her historical materials is ultimately directed towards current debates and imperatives concerning the Anthropocene and biodiversity.

Still in the realm of insects, in the final contribution to this volume, V.E. Mandrij makes a comparison between the work of the painter Otto Marseus van Schrieck (c. 1621-1678) and the present-day German painter Maximilian Prüfer (b. 1986). What these artists have in common is that they integrate wings of butterflies and other animal substances in their works of art. Whereas Marseus seems to have blurred the distinction between nature and art in a more provocative way - putting insects and reptiles literally from the margins to the centre of works of art - Prüfer, according to Mandrij, is more concerned with ethical and ecological issues. Van Schrieck seemingly intended to invoke a sense of wonder for the creatures that were traditionally seen as the lowest stages in the 'great chain of being'. Echoing the work of Descartes, as understood by his close friend Swammerdam, Van Schrieck considered snakes, toads and insects as worthy of painting as princes and Biblical scenes. Prüfer - as Mandrij understands him - mainly aims aims to raise our awareness, as humans, of the beauty and fragility of nature and the ecological disaster which we have created for ourselves and other animals. 
Notes

1 Guerrini 2002, 56; Guerrini 2003, 33.

2 A recent example is Almiron 2021: 'It was during the Enlightenment that we humans fully erased our animal nature from our self-conception and language, especially under the heavy stamp of Cartesian thought' (57). See also Kalof 2017.

3 Berger 1977.

4 See, for example, Waldau 2013, 144-145: 'Descartes argued again and again that any and all animals outside our species have no mind and are devoid of reason (...) It is surprisingly obvious to anyone who takes a single course in Animal Studies today that Descartes chose not to take other living beings seriously. Some features of his ignorance, then, were arguably self-inflicted'.

5 Kalof 2017.

6 Fudge 2002.

7 Derrida 2008; Chrulew \& Wadiwel 2017.

8 Waldau 2013, 127-147.

9 Davids 1989; Van Zanden et al. 2021.

10 See, for example, Dupré \& Lüthy 2011 and Rikken 2016.

11 For a recent, fascinating account see Van den Berg 2021.

12 Rikken 2016; Egmond 2016.

13 Jansen 1952, 287-319; Sullivan 1981.

14 Sorenson 2009, 95-96.

15 Compare Govaert Flink, A young archer, c. 1639-1640, oil on panel, $66.2 \times 5^{0.8} \mathrm{~cm}$, London, Wallace Collection.

16 Bindman 2000, 151.

17 See, most recently, Kontler 2020 and Vartija 2021.

18 For the reasoning behind this demarcation in time, see Van Zanden et al. 2021, 11-29 and 97-175.
19 See the contribution by V.E. Mandrij in this volume.

20 See the contribution by Thomas Balfe in this volume.

21 See the contribution by Joan Greer in this volume.

22 See, for example, French 1994 and Enenkel \& Smith 2007.

23 Lovejoy 1933; Jorink 2010.

24 Aristotle, Historia animalium, IX, 9.

25 Aristotle, Historia animalium, 588b3-6.

26 Pliny 1940; X, lxxx11, 171; XI, xlix, 136.

27 Ibid, VII, i, 1.

28 See, for example, Enenkel \& Smith 2007.

29 Sambursky 1959; Osler 1991.

30 Genesis 1:28

31 Much has been written about Physiologus: relevant in the context of this volume is Cohen 2008.

32 Bakker 2018.

33 Dackerman 2011. See, for the interplay between observation, drawings, prints and paintings in this context, Kusukawa 2012; Rikken 2016 and Egmond 2016.

34 Ashworth 1984; Ashworth 1985; Dackerman 2011.

35 Dackerman 2011, 162-184.

36 Ashworth 1996; Egmond 2016; Egmond 2018; Leu \& Opitz 2019.

37 Gessner 1551-1587.

38 Dackerman 2011, 158-159.

39 Of the extensive literature on this subject, we mention only Enenkel \& Smith 2017.

40 Ashworth 1990; Ashworth 1996.

41 Davids 1989, 23-30; Matthey 2002, 139.

42 Davids 1989, 48-50.

43 Davids 1989, 12-15.

44 Van Zanden et al. 2021, 97-110.

45 Davids 1989, 23-30; Van Zanden et al. 2021, 45-58.

46 De Rijk 1985.
47 See the contribution by Maurice Saß in this volume.

48 Jorink 2010, 68.

49 Bass 2019.

50 Ashworth 1985; Geirnaert \& Smith 1992; Van Vaeck 1993; Balfe 2021. See also https://www.leidenartsinsocietyblog.nl/ articles/one-hundred-and-eleven-drawings-identified-as-the-work-of-marcusgheeraerts.

51 As the motto of the Warachtighe Fabulen der Dieren reminded the reader, quoting the Book of Psalms (8:6-9): God created Man '(...) to have dominion over the works of thy hands; thou hast put all things under his feet: All sheep and oxen, yea, and the beasts of the field; The fowl of the air, and the fish of the sea, and whatsoever passeth through the paths of the seas'.

52 Rikken 2016; Egmond 2016.

53 Baadj 2016; Rijks 2019; Rijks 2021.

54 Jorink 2010; Dupré \& Lüthy 2011; Egmond 2016.

55 Roscam Abbing 2021.

56 Van Nouhuys 1998.

57 Begley 2020.

58 Gassendi to Van Helmont, 8 June 1629, translation in Taussic 2004, 33-40.

59 Des Chene 2001; Bertoloni Meli 2016.

60 Begley 2020.

61 Cottingham 1978; Guerrini 2003; Zittel 2011; Franco 2018.

62 Guerrini 2003, 21-47.

63 Jorink 2010, 270-290.

64 Jorink 2010, 350-370.

65 Descartes 1637, part 5.

66 Haraway 2003; Derrida 2008.

67 Van Dooren 2020; Van Dooren et al. 2016; Kimmerer 2013.

\section{Bibliography}

\section{Almiron 2021}

N. Almiron, 'Communicating solidarity. The ethics of representing human and nonhuman distant suffering', in: N. Khazaal \& N. Almiron (eds.), Like an animal. Critical animal studies approaches to borders, displacement, and othering, Leiden \& Boston 2021, 51-75.

\section{Anderson 2015}

B.C. Anderson, 'Evidence of cochineal's use in painting', Journal of Interdisciplinary History 45 (2015), 337-366.

\section{Ashworth 1984}

W.B. Ashworth Jr., 'Marcus Gheeraerts and the Aesopic connection in seventeenth-century scientific illustration', Art Journal 44 (1984), 132138.

\section{Ashworth 1985}

W.B. Ashworth Jr., 'The persistent beast. Recurring images in early zoological illustrations', in: J. Ackerman (ed.), The natural sciences and the arts. Aspects of interaction from the Renaissance to the 2oth century, Uppsala 1985, 46-66.

\section{Ashworth 1990}

W.B. Ashworth Jr., 'Natural history and the emblematic world view', in: D. Lindberg \& R. Westman (eds.), Reappraisals of the Scientific Revolution, Cambridge 1990, 300-323.

\section{Ashworth 1996}

W.B. Ashworth Jr., 'Emblematic natural history of the Renaissance', in: N. Jardine, J.A. Secord \& E.C. Spary (eds.), Cultures of natural history, Cambridge 1996, 17-37. 
Baadj 2016

N. Baadj, Jan van Kessel (1626-1679). Crafting a natural history of art in Earby Modern Antwerp, Turnhout 2016.

Bakker 2018

B. Bakker, 'Bernhard von Breydenbach and Erhard Reuwich of Utrecht. Pioneers in the theory and practice of the lifelike printed image', Simiolus 40 (2018), 231-257.

Balfe 2021

T. Balfe, 'Learned fable, living world. Artistry, knowledge and attention to nature in two Aesopic paintings by Joannes Fyt', Journal of Historians of Netherlandish Art 13 (2021), 1-27.

Balfe \& Woodall 2019

T. Balfe \& J. Woodall, 'Introduction. From living presence to lively likeness - the lives of ad vivum', in: T. Balfe, J. Woodall \& C. Zittel (eds.), Ad vivum? Visual materials and the vocabulary of life-likeness in Europe before 180o, Leiden \& Boston 2019, 1-43.

Bass 2019

M.A. Bass, Insect artifice. Nature and art in the Dutch Revolt, Princeton \& Oxford 2019.

Begley 2020

J. Begley, 'Pierre Gassendi and the humanist case for a vegetarian diet', in: H. Haara, K. Stapelbroek \& M. Immanen (eds.), Passions, politics and the limits of society, Berlin 2020, 75-88.

Berger 1977

J. Berger, 'Why look at animals?' (1977), reprinted in: About looking, New York 1991, 3-28.

Berg 2021

A.van den Berg. De leeuw van Alpi. Handle en wandel van een beestenman, Amsterdam 2021.

Bertoloni Meli 2013

D. Bertoloni Meli, 'Early modern experimentation on live animals', Journal of the History of Biology 46 (2013), 199-226.

Bertoloni Meli 2016

D. Bertoloni Meli, 'Machines of the body in the seventeenth century', in: P. Distelzweig, B. Goldberg \& E. Ragland (eds.), Early modern medicine and natural philosophy, Berlin 2016, 91-116.

\section{Bindman 2000}

D. Bindman, Ape to Apollo. Aesthetics and the idea of race in the eighteenth century, London 2000.

\section{Calarco \& Atterton 2004}

M. Calarco \& P. Atterton (eds.), Animal philosophy. Essential readings in Continental thought, London \& New York 2004.

\section{Descartes 1637}

R. Descartes, Discours de la méthode, Leiden 1637.

Des Chene 2001

D. Des Chene, Spirits and clocks. Machine and organism in Descartes, Ithaca 2001.

\section{Chrulew \& Wadiwel 2017}

M. Chrulew \& D.J. Wadiwel (eds.), Foucault and animals, Leiden 2017.

Cockram \& Wells 2018

S. Cockram \& A. Wells (eds.), Interspecies interactions. Animals and humans between the Middle Ages and modernity, London \& New York 2018.

\section{Cohen 2008}

S. Cohen, Animals as disguised symbols in Renaissance art, Leiden \& Boston 2008.

\section{Cottingham 1978}

J. Cottingham, “'A brute to the brutes?". Descartes' treatise of animals', Philosophy 53 (1978), 551-559.

\section{Dackerman 2011}

S. Dackerman (ed.), Prints and the pursuit of knowledge in early modern Europe, Harvard 2011.

\section{Davids 1989}

K. Davids, Dieren en Nederlanders. Zeven eeuwen lief en leed, Utrecht 1989 .

\section{DeMello 2010}

M. DeMello, Teaching the animal. Human-animal studies across the disciplines, New York 2010.

\section{Derrida 2008}

J. Derrida, The animal that therefore I am (D. Wills, trans.), New York 2008.

\section{Van Dooren 2020}

T. van Dooren, 'Pangolins and pandemics. The real source of this crisis is human, not animal', New Matilda, 22 March 2020, https://newmatilda. com/2020/03/22/pangolins-and-pandemics-the-real-source-of-thiscrisis-is-human-not-animal/.

Van Dooren et al. 2016

T. van Dooren, E. Kirksey \& U. Münster, 'Multispecies studies. Cultivating arts of attentiveness', Environmental Humanities 8 (2016), 1-2

Dupré \& Lüthy 2011

S. Dupré \& C. Lüthy (eds.), Silent messengers. The world of goods and the circulation of knowledge in the early modern Netherlands, Berlin 2011.

\section{Egmond 2016}

F. Egmond, Eye for detail. Images of plants and animals in art and science, 1500-1630, London 2016.

\section{Egmond 2018}

F. Egmond, Conrad Gessners 'Thierbuch' Die Originalzeichnungen, Darmstadt 2018.

\section{Enenkel \& Smith 2007}

K. Enenkel \& P. Smith (eds.), Early modern zoology. The construction of animals in science, literature and the visual arts, Leiden 2007.

\section{Enenkel \& Smith 2017}

K. Enenkel \& P.J. Smith (eds.), Emblems and the natural world, Leiden \& Boston 2017. 
Franco 2018

A.B. Franco, 'Descartes' dog. A clock with passions?', Philosophia 46 (2018) 101-130.

\section{French 1994}

R. French, Ancient natural history. Histories of nature, London 1994.

\section{Fudge 2002}

E. Fudge, 'A left-handed blow. Writing the history of animals', in: N. Rothfels (ed.), Representing animals, Bloomington 2002, 3-18.

\section{Geirnaert \& Smith 1992}

D. Geirnaert \& P.J. Smith, “Tussen fabel en embleem. De warachtighe fabulen der dieren (1567)', Literatuur 9 (1992), 22-33.

\section{Gessner 1551-1587}

C. Gessner, Historice animalium, Zurich 1551-1587, 4 vols.

\section{Guerrini 2002}

A. Guerrini, 'The rhetorics of animal rights', in: J.P. Gluck, T. DiPasquale \& F.B. Orleans (eds.), Applied ethics in animal research. Philosophy, regulation, and laboratory applications, Lafayette 2002, 55-76.

\section{Guerrini 2003}

A.Guerrini, Experimenting with humans and animals. From Galen to animal rights, Baltimore 2003.

\section{Haraway 2003}

D. Haraway, The companion species manifesto. Dogs, people, and significant otherness, Chicago 2003.

\section{Janson $195^{2}$}

J.H. Janson, Apes and Ape Lore in the Middle Ages and the Renaissance, London 1952.

\section{Jorink 2010}

E. Jorink, Reading the book of nature in the Dutch Golden Age, 1575-1715, Leiden \& Boston 2010

\section{Jorink \& Ramakers 2011}

E. Jorink \& B. Ramakers (eds.), Art and science in the early modern Netherlands, Zwolle 2011, Netherlands Yearbook for History of Art 61 (2011).

\section{Kalof 2017}

L. Kalof (ed.), The Oxford handbook of animal studies, Oxford 2017.

\section{Kimmerer 2013}

R.W. Kimmerer, 'Learning the grammar of animacy', in: Braiding sweetgrass. Indigenous wisdom, scientific knowledge, and the teachings of plants, Minneapolis 2013, 48-59.

\section{Kontler 2020}

L. Kontler, 'Inventing "humanity". Early-modern perspectives', in: H. Haara, K. Stapelbroek \& M. Immanen (eds.), Passions, politics and the limits of society, Berlin 2020, 26-46.

\section{Kusukawa 2012}

S. Kusukawa, Picturing the Book of Nature. Image, Text, and Argument in Sixteenth-Century Human Anatomy and Medical Botany, Chicago 2012.

\section{Landwehr 1988}

J. Landwehr, Emblem and fable books printed in the Low Countries, 15421813. A bibliography (3rd rev. ed.), Utrecht 1988.

\section{Lehman et al. 2013}

A.-S. Lehman, F. Scholten \& P. Chapman (eds.), Meaning in materials. Netherlandish art, 1400-1800, Leiden 2013 (= Netherlands Yearbook for the History of Art 62 [2013]).

\section{Leu \& Opitz 2019}

U. Leu \& P. Opitz (eds.), Conrad Gessner (1516-1565). Die Renaissance der Wissenschaften / The renaissance of learning, Berlin \& Boston 2019.

Lovejoy 1933

A. Lovejoy, The great chain of being. The history of an idea, Harvard 1933

Matthey 2002

I. Matthey, Vincken moeten vincken locken. Vijf eeuwen vangst van zangvogels en kwartels in Holland, Hilversum 2002.

Van Nouhuys 1998

T. van Nouhuys, The age of two-faced Janus. The comets of 1577 and 1618 and the decline of the Aristotelian world view in the Netherlands, Leiden 1998.

Ogilvie 2006

B. Ogilvie, The science of describing. Natural history in Renaissance Europe, Chicago 2006.

Osler 1991

M. Osler (ed.), Atoms, pneuma and tranquillity. Stoic and Epicurean themes in European thought, Cambridge 1991.

Pliny 1938-1968

Pliny the Elder, Natural history (H. Rackham et al., trans.), Harvard 19381968,10 vols.

De Rijk 1985

J.H. de Rijk, 'Wolven in Nederland. Een samenvatting van de historische gegevens', Huid en Haar 1985, 73-84.

Rijks 2019

M. Rijks, 'A painter, a collector, and a horseshoe crab. Connoisseurs of art and nature in early modern Antwerp', Journal of the History of Collections 31 (2019), 343-361.

Rijks 2021

M. Rijks, Artists' and artisans' collections in early modern Antwerp. Catalysts of innovation, Turnhout 2021.

\section{Rikken 2016}

M. Rikken, Dieren verbeeld. Diervoorstellingen in tekeningen, prenten en schilderijen door kunstenaars uit de Zuidelijke Nederlanden tussen $155^{\circ}$ en 1630 , Leiden 2016 (unpub. diss. Leiden University).

\section{Ritvo 2002}

H. Ritvo, 'History and animal studies', Society \& Animals 10 (2002), 403406 . 
Roscam Abbing 2021

M. Roscam Abbing, Rembrandt's elephant. Following in Hansken's footsteps, Amstelveen 2021.

Sambursky 1959

S. Sambursky, The physics of the Stoics, London 1959.

Smith et al. 2020

P.H. Smith et al. (eds.), Secrets of craft and nature in Renaissance France. A digital critical edition and English translation of BNF Ms. Fr. 64o, New York 2020.

Sorenson 2009

J. Sorenson, Ape, London 2009

Sullivan 1981

M. Sullivan, "Peter Bruegel the Elder's Two Monkeys: A New Interpretation", The Art Bulletin, 63 (1981), 114-126.

Taussic 2004

S. Taussic, Pierre Gassendi (1592-1655). Lettres Latines (2 vols) Turnhout 2004 .

\section{Van Vaeck 1993}

M. van Vaeck, 'Sixteenth- and seventeenth-century Dutch "emblematic" fable books from the Gheeraerts filiation', Emblematica 7 (1993), 25-38.

\section{Vartija 2021}

D.Vartija, The color of equality. Race and common humanity in Enlightenment thought, Pittsburg 2021.

Waldau 2013

P. Waldau, Animal studies. An introduction, Oxford 2013.

Wolloch 2006

N. Wolloch, Subjugated animals. Animals and anthropocentrism in early modern European culture, Amherst 2006.

Van Zanden et al. 2021

J.L. van Zanden et al., De ontdekking van de natuur. De ontwikkeling van biodiversiteit in Nederland van de IJstijd tot de $21^{e}$ eeuw, Amsterdam 2021.

Zittel 2011

C. Zittel, 'Conflicting pictures. Illustrating Descartes' Traité de l'homme', in: S. Dupré \& C. Lüthy (eds.), Silent messengers. The world of goods and the circulation of knowledge in the early modern Netherlands, Berlin 2011, 217-26o. 